\title{
Music as a Universal Bond and Bridge Between the Physical and the Divine: Transcultural and Medieval Perspectives
}

\author{
Albrecht Classen \\ University Distinguished Professor, Director of Undergraduate Studies, Dept. of German Studies, \\ University of Arizona. Email: aclassen@arizona.edu
}

\begin{abstract}
This article accepts the challenge to reflect on the cultural history of music as a transcultural and universally human phenomenon, particularly in the medieval context. To what extent has music played the same or at least similar function in endless cultural contexts all over the world from the past to the present? We know for sure that music has always been present at all age groups, in all ethnic groups, among all genders, and throughout time. There have always been local, ethnic types of music (folklore), and universally accepted manifestations of music (esp. classical music). The emphasis here rests, after an extensive study of music in global cultural-historical terms, on comments about music in medieval philosophy, mysticism, and literature because here we discover fundamental notions about music being the medium to connect the individual with the cosmic harmony, hence with the divine. In literary texts, above all, music was identified as the critical expression of identity, love, and religion.
\end{abstract}

\section{Keywords}

Transcultural music; classic music; music in cultural-historical terms; The Beatles; Martianus Capella; Boethius; Gottfried von Strassburg; Jörg Wickram; Hermann Hesse

\section{Introduction: Universals of Music}

\section{Transculturality, Interculturality, and Musical Revolutions}

Ethno-musicologists would easily agree with the observation that people across the world have always influenced, shaped, and transformed their world by means of music, have enjoyed music, and have communicated with each other in musical terms. Each culture, people, historical period, social class, and ethnic group has regularly embraced its own distinct musical expression, and yet, broadly speaking, music is a fundamentally human phenomenon and experience shared by all people because it provides comfort, entertainment, stimulation, inspiration, hope, and because it reflects emotions or creates 
those in the first place. However, there is no universal agreement at all what constitutes 'good' versus 'bad' music, 'elite' versus 'low' music ('high culture' versus 'low culture'), authentic versus unauthentic music, how to define music as such in the first place, and to what extent personal tastes and ideas matter in such a discussion. Moreover, there are intensive debates as to the possibility of pursuing transcultural musical history, which Tobias Robert Klein and Mark Hijleh have recently promoted once again in light of early medieval neumes and more or less contemporary Buddhistic Chinese music notations (Hijleh; Klein; cf. also Goebel's observations in his contribution to this volume).

Music is also a representation of unique aspects of every culture and its values, which certainly change over time, and sometimes even in a rapid, perhaps revolutionary manner. Paradigm shifts often come about also in terms of music, such as when Martin Luther (1483-1546) introduced his new Protestant Church and strengthened the people's involvement by providing new hymns composed in the vernacular Early New High German during the 1520s (Möller; for a complete list, see online at: https://en.wikipedia.org/wiki/List_of_hymns_by_Martin_Luther, last accessed on June 16, 2021. For global reflections on the paradigm shift, see the contributions to Classen, ed., 2019. Unfortunately, musical history was not considered in that volume).

The rise of Rock'n Roll in the late 1940s and 1950s, the emergence of Rock in the 1960s, and especially the meteoric stardom of The Beatles, the famous band founded in Liverpool in 1960, meant a radical break in musical terms from the older generation of composers and performers, granting musical counterculture and popular music the new status of being broadly defined standard and reputable entertainment. Ironically, however, their 'revolutionary' music is today already considered as belonging to the categories of 'Oldies' or 'Classical Rock.' It would be hard to imagine any country in this world where the music of The Beatles would not be deeply recognized as foundational for modernity (Womack, ed.). Of course, ever since the heyday of these famous British musicians, contemporary bands and singers have picked up the baton from their predecessors and have marched forward into many new directions from the 1970s until the present, whether we think of Hip Hop (Rap) since the 1970s and Hardcore Punk since the 1980s (Norman; Larkin, ed.).

This small but powerful example of The Beatles and their musical revolution could be easily traced backward by way of the metaphor of a continuous staircase of major composers who influenced each other and broke away as well, so when we think of the highly innovative operas by Richard Wagner (1813-1883), the stunning symphonies by Ludwig van Beethoven (1770-1827), the major impact exerted by Johann Sebastian Bach (1685-1750), the extensive paradigm shift brought about by Johannes Ockeghem (ca. 1410-1497) and other Renaissance composers. Not surprisingly, the same phenomenon applies to late, high, and early medieval music, and from there we can easily move into late antiquity, etc., including parallel analogies in other non-western cultures (Petersen; 
Classen, "Soundscapes"). ${ }^{i}$ In short, music possesses as much history as literature or the arts, and we can detect, for instance, many bridges between Arabic and Asian music on the one hand and European music on the other when we endeavor to carry out comparative analyses. In short, music is a global and transcultural phenomenon, easily migrating from country to country, from continent to continent and this especially in the modern period with its ever-expanding new media and hence improved accessibilities unfortunately a world increasingly filled with sound and noise, which increasingly prevents us from listening and hearing in the deep sense of the word. The more we hear today the less we can auralize, since silence becomes so rare, so precious.

However, music by itself is easily appreciated and understood across all linguistic, social, ethnic, and historical boundaries, though it also requires translations and interpretations since the categories of musical aesthetics differ from culture or social group to the next, at least on a superficial level (Higgins; Schafer). ${ }^{. i}$ There is a difference between hearing meaninglessly and appreciating sound as something meaningful. This article examines the particular phenomenon of music creating resonance in a relatively ideology-free space and trans-temporally, even if we still require a considerable amount of understanding, sensitivity, empathy, and intuition to gain full access to music as such.

Yet, to what extent and how much folkloric music migrates, depends on many different factors, and cannot be globally determined easily. Nevertheless, we can be certain that there have always been differences between courtly music and music performed by the ordinary people, between learned, sophisticated music and simple and popular music, whether in Japaniii or in Ethiopia, iv then between Church music and rural music, between spiritual and entertaining music, and so on, as the situation in India, for instance, underscores impressively (classical, folk, and popular). ${ }^{\vee}$

A fascinating example of interaction, dialogue, and integration, however, proves to be Antonín Dvořák's Symphony no. 9 in E minor, "From the New World" composed in 1893, which might serve uniquely well as a reflection of the merging of classical European orchestral elements with American folklore in musical terms. At closer analysis, we realize that the entire history of music is filled with such examples, whether we think of Arabic influence on early twelfth-century troubadour music in the Provence, or of African music on modern-day Black American music and elsewhere. As Paulina Tendera and Wojciech Rubiś insightfully point out,

musicians create a fusion of many traditions. They incorporate folk instrumentation such as Welsh and Celtic harps and African drums; diverse kinds of composition (in addition to Western classical music major and minor tonal harmony, modal harmony based on a single tonal centre is used); the complex polytonal and polyrhythmic systems of the musically advanced ethnic cultures of India, the Balkan 
and Iberian Peninsulas (flamenco), and Gypsy (manouche) and Jewish (klezmer music) communities scattered all over the world; and eclectically selected components of Tibetan chant, Chinese koto music, Indian ragas, etc. Immigration is a significant influence here. For example, in Paris, World Music demonstrates the strong cultural influences of Morocco, Cote d'Ivoire, Guinea, Mali and Senegal, while on the American continent (South America), immigrants from Europe have contributed to creating types of music such as Argentine tango and bossa nova. The richest mix of cultures, also known as Creole, in the Caribbean has greatly contributed to the development of Latin American music and such styles as salsa, guancanco, and cha-cha. Finally, from the encounter of the descendants of black slaves with Christian culture (the USA), blues, soul, gospel, ragtime, and swing evolved, culminating in mainstream jazz (Tendera and Rubiś; Strohm).

On a personal note, my own way to classical music was paved by jazzed up versions of Mozart's symphonies which facilitated my aesthetic pleasure when I was still in my youth. A wonderful example proves to be Waldo De Los Rios's (1934-1977) "Mozart - Sérénade 13 en sol majeur 'Eine kleine Nachtmusik'."vi

Significantly, until today virtually all music by countless artistic individuals from throughout time continues to have the power to appeal to us irrespective of the historical and ethnic distance to the modern audience. Many times, modern western audiences might respond at first with some surprise to medieval troubadour poetry, or to the melodious music from Hawai'i and Tahiti, but melody, harmony, and joy constitute significant sensory bridges beyond all epistemological barriers. Many people continue to listen just as happily to Baroque fugues (Bach) as to post-Romantic symphonies by Gustav Mahler (1860-1911) or Bedřich Smetana (1824-1884). However, whether Arnold Schönberg (1874-1951) truly achieved a major breakthrough with his atonal music in the West, is still not fully determined, although symphonic orchestras from across the world by now routinely include his and similar compositions in their repertoires, acknowledging the brilliance and genius of Schönberg and now Paul Hindemith (1895-1963), for instance. On a personal, admittedly very subjective level, it seems contradictory to me to create non-harmonic music when harmony is the fundamental element characterizing and determining music, although I would have to agree with Rolf Goebel's comment to my draft version of this paper that the twelve-tone music consists of a highly structured system as well (Roig-Francoli). vii Music without a hierarchical pitch where the notes of the chromatic scale function independently of one another appears to be extremely abstract and non-communicative, whether this is representative of the postmodern world with its chaotic properties or not. Of course, we might have to qualify this further, and would have to argue that this type of music simply looked for a more abstract form of communication on a highly abstract level. 
Despite all those differences in styles, melodies, modes, and tonality, we can be certain that music permeates the world and could be regarded as the aesthetic voice of all people. Without music, there would be a huge gap in all of human culture, and people would become virtually mute. We would not be able to understand religion, the arts, spirituality, human emotions, and the fundamental rhythm of this world.

Of course, we have to accept that the differences between, say, Hawai'ian slackkey or hula music on the one hand, and Mexican mariachi could not be bigger, and this also applies to Peruvian versus Bavarian, Siberian versus Indonesian music. Indian and Arabic music operates with different concepts compared to western music, particularly with regards to tonality, not even considering the different music instruments, but we can draw from virtually all cultures to recognize the uniqueness and beauty of music as such, irrespective of individual manifestation determined by the cultural-historical context. Folk music and learned music, entertaining music versus sophisticated music, Jazz versus orchestral music, etc. are only some of the characteristic and yet contrastive pairs all over the world, and as cultural historians, we should never ignore the one or the other, especially in historical terms. In short, we face here a rich kaleidoscope of musical facets, but the foundation of music always remains the same.

After all, people, whether educated in music or not, appreciate music in some way or the other, if we could not even claim that they need music for their own self-expression, their emotions, their identity. Small children begin from very early on to express themselves musically, perhaps even earlier than formulating complete words and sentences. And the mental health of infants is commonly improved if they are exposed from early on to music (Kobus). viii

It would be useless to attempt here to discriminate by means of value judgments among folk music, popular music, bar music, entertaining music, radio or internet music, operas, symphonies, pop, disco music, etc. At any rate, with the help of the computer and other technical media, anyone can nowadays listen to any type of music played on an infinitude of musical instruments, as solos or by orchestras. We are dealing, after all, with universals, that is, human identity and culture, but neither one is historically limited. Nothing stands in the way for modern audiences to enjoy the performance of medieval Gregorian chant or courtly love poetry, or Baroque toccatas and Romantic piano pieces. Music is, after all, the voice of all people across the globe and from throughout time. It would also be important to consider that true music (classical, folk, hip hop, etc.) combats racism, agism, and sexism, as much as it has often been influenced by those ideologies (Thurman). ${ }^{\text {ix }}$

This observation regarding the universal expressivity of music was already addressed in a significant fashion by late antique and medieval thinkers, for whom music 
was profoundly a medium of spiritual enhancement, a most esoteric medium to reach out to God during the liturgy, that is, in a sacramental way, or, as Hugh of St. Victor formulated it in the thirteenth century, to achieve "salvation administered by the Church" (Petersen 6). This aspect underscores a significant phenomenon, one related to the timeless quality of all music. Music is not simply or exclusively autochthonic, but often the result of crosscultural and cross-chronological exchanges and fertilizations, a fact which forces us to probe more deeply how much it mirrors a universal and timeless message building bridges between the various cultures and across many historical divides.

Spirituality, above all, as expressed by music, has always proven to be a shared human experience and all of its countless individual manifestations, and all religions have drawn intensively from music to express the intangible, esoteric, and divine in its abstract, highly elusive nature, and yet being close to the Godhead, whether we think of Buddhism, Hinduism, Christianity, Native-American spirituality, or animism (Baumann; Sholl and van Maas, ed.; Boyce-Tillman, ed., 2017; Boyce-Tillman, Roberts, and Erricker, ed., 2019; Coward; Taiwo). Could we not even postulate that music is religion, or that religion can possibly be defined by or as music, an aesthetic experience that paves the way for the transcendence of the individual's material existence? The post-Romantic German author Heinrich von Kleist seems to have indicated that most powerfully in his short story "Die heilige Cäcilie oder die Gewalt der Musik" (1810; St. Cecilia, or the Power of Music) where a group of iconoclasts is prevented from carrying out their violent act when they are suddenly exposed to a nuns' choir and then appear to lose their minds, though they ultimately die peacefully in an asylum (Tkotzyk; Schirrmacher). We could even go one step further and claim that much of all of Romanticism was deeply determined by music as a spiritual language addressing all people throughout time. I will return to this issue below.

\section{History of Music}

Music was recognized particularly in the Middle Ages as an esoteric, spiritual, and aesthetic phenomenon, as a medium for the direct conversation with God. There was no Christian church service or mass without some liturgical music, mostly Gregorian chant. In particular, the subsequent part of this paper will bring some of those voices to the fore in recognition of their time- and culture-transcendent relevance and discuss what we could learn from medieval music theoreticians concerning the universal relevance of music.

We as listeners do not need to understand fully the historical background, the language used by singers, or the many types of different musical instruments employed when we want to appreciate what is offered to us during a concert, as much as such information might serve well for a better comprehension. Consequently, folk music is just as valuable as inner-city music in North American cities, and Mongolian music is as 
important for the people involved in it as Afghan music from the past and the present. Could we thus claim that music is transcultural, a language that everyone can understand throughout time across the world? Would there be the possibility that we could overcome political, ideological, ethnic or moral differences by way of music? What discourse does music hence represent? Is it not the one medium which all people in this world happily join and share? Or are there social and educational, if not even racial barriers, at least superficially?

Considering the commonly very abstract nature of music, ${ }^{x}$ we might want to agree with some of these notions, but much also depends on the cultural context and the intention with which music is performed. For example, music created for and presented to fascist or communist regimes, music representing colonial, military, or dictatorial powers, would not be welcome by leftists, revolutionaries, critical thinkers, or liberals. Music that glorified racism, slavery, and colonialism leaves a bad taste in our mouths today, at least for most people with a liberal and intellectually open mindset. But then there are cases such as the globally admired "Amazing Grace," a Christian hymn published in 1779 based on the verses composed by the English poet and Anglican clergyman John Newton (1725-1807) in 1772. He was involved in the Atlantic slave trade, but in 1748 his vessel was near shipwreck during a storm off the coast of County Donegal, Ireland. He did not drown, and he continued with his business as a slave trader until 1754 or 1755 , when he abandoned this profession altogether and turned to theology and was ordained priest in 1764. In memory of his near-drowning, he composed his song "Amazing Grace" to accompany a sermon on New Year's Day of 1773, which was first printed in 1779. The song centrally focuses on a person's trust in God and the power of spiritual conversion, but we should not forget that Newton's experience was, after all, the direct result of his work with slaves (Phipps; Aitken; for a good summary, see https://en.wikipedia.org/wiki/Amazing_Grace (last accessed on June 16, 2021). How neutral can music be, if ever? Or, does music, do songs transcend the ideological, spiritual, or historical content by means of their melodies, irrespective of the words?

In fact, the opposite would certainly be the case as well, so there is certainly a tendency for music to become ideological, supporting or fighting a political system. We tend to disagree about what music tries to express, but the aesthetic dimension and relevance of music could remain universally shared (Kirsch, ed.; Seebass, ed.; Lee and Jianmei, ed.). However, if we consider that many times Nazi guards in German concentration camps forced some prisoners to play classical music while others were led to the gas chambers, we would shudder about the extent to which music could be abused. At the same time, many Holocaust victims resorted to music on their own to compensate for their inhuman suffering and constant death experience (Fackler; Westermann see also https://holocaustmusic.ort.org/places/camps/death-camps/auschwitz/; and https://theconversation.com/how-the-nazis-used-music-to-celebrate-and-facilitate- 
murder-155704; all last accessed on June 15, 20210).

In short, we face a considerable dilemma, with music not being exempt from outside, that is, political and ideological influences, and yet regularly abstract enough to avoid such manipulations, all depending on the circumstances. It could also be argued that historical barriers might make the reception of older music by the modern generation rather problematic, if not impossible. And yet, with just slight adaptations, all such hurdles in music could be overcome in favor of global perceptions of what music could mean and achieve. Not by accident has medieval music by the troubadours and the minnesingers gained tremendously in popularity in the last half century and more (Gülke; see also the numerous studies by Müller). It is, after all, a cultural language, though often without words, and the communication achieved by music might be highly productive or seductive, misleading or manipulating. One interesting example would be Franz Liszt's "Les Préludes" (composed between 1844 and 1859), a symphonic poem, as it is commonly called. The irony of this piece was its use for highly ideological purposes during the Third Reich: "The closing fanfare of Les préludes was used for news bulletins by the ReichsRundfunk- Gesellschaft during the Nazi regime. The fanfare would cue the announcer to say, 'Das Oberkommando der Wehrmacht gibt bekannt...' (The supreme command of the armed forces announces...) before relating the Nazi's latest victory. Germans were so conditioned by the militaristic usage of Les préludes that there was a de facto ban on the piece after the war. ${ }^{\prime x i}$

Today, however, those associations with the Nazi regime are mostly forgotten or dismissed, no longer relevant for our appreciation of this musical composition, and instead, Liszt's piece is acknowledged as one of his masterworks which everyone can and should enjoy. Music is defenseless against misappropriation, for capitalistic, commercial, political, military, or religious purposes, such as the Carmina Burana by Carl Orff (1935 to 1936, based on the early thirteenth-century collection of Latin and Middle High German songs), and yet it continues to reverberate throughout the world, freely available to anyone for whatever purposes, claiming its own aesthetic, ethical, and philosophical realm. This begs the question, once again, what constitutes music in the first place, behind its myriad of manifestations throughout time and in cultures across the world, and this beyond the mechanical or artistic arrangement of sounds in time according to some rhythm, mode, medium, timbre, and harmony. But in essence, as we can assume, there has always been a direct connection between the human, the material, and the divine, spiritual dimension via music (Gallope).

\section{Medieval Music Theory}


On the basis of these very general observations, let us next turn to more specific aspects relevant for music and music history. Following I will explore how music was perceived and discussed in the Middle Ages from a philosophical and a literary perspective because the foundation of musical appreciation in theoretical terms was laid already in the fifth century, which maintained its critical importance far into the sixteenth century and beyond. The intention cannot be to achieve a comprehensive overview, which would be tantamount to carrying owls to Athens (Kügle). Instead, my purpose is to explore a few unique approaches to music during that period which might assist us today in comprehending more universal aspects of music which are characteristic and constitutive of music throughout time which thus could build aesthetic and spiritual bridges between the western medieval world and us today.

Perhaps similar to the concepts by Rudolf Steiner regarding the role of music as a mirror of the individual in his/her growth from childhood to adulthood with respect to the micro- and macrocosmic perspectives probably deeply influenced by medieval and earlier sources, ${ }^{x i i}$ in late antiquity an educational system emerged for advanced learning which was to maintain its central role well into the Renaissance. Martianus Capella (fl. ca. 410-420) formulated in his De nuptiis philologiae et Mercuriithe principles of all university studies, as we would call it today, and assigned music one of the most significant roles. After having completed their trivium (rhetoric, logic, and grammar), students would pick up their quadrivium, which included arithmetic, geometry, astronomy, and music (Martianus Capella 1836, online now at: https://archive.org/details/denuptiisphilolo00martuoft, last accessed on June 13, 2021; for an English translation, see Martianus Capella 1977). Arithmetic explained the world in abstract terms, geometry in spatial terms, music in chronological or temporal terms, and astronomy in spatial and chronological/temporal terms (Grebe). As we learn, for instance, harmony is "able to soothe the cares of the gods, gladdening the heavens with her song and rhythms; and she desires only to make our palaces resound, detesting the everincreasing dullness and spiritlessness of the earthborn, resulting from their lack of skill in melic verse" (349). By means of music, here described in mythologizing terms, life returns to all inanimate objects and spurs forward nature: "with song Amphion brought life again to bodies stiff with cold, made mountains animate, and gave to hard rocks sensibilities, teaching them to follow his refrains. The walls of Thebes, obedient to his song, were raised to the strains of his sweet lyre, and he provided a protection" (352).

Amphion, one of the twin sons of Zeus and Antiope, is identified as the creator of universal harmony, which connects all and every element in concentric circles, all carried by music: "Harmony bore what appeared to be a shield, circular over-all, with many inner circles, the whole interwoven, with remarkable configurations. The encompassing circles of this shield were attuned to each other, and from the circular chords there poured forth a concord of all the modes" (352-53). This spiritual music is described as a "secret fire and 
inextinguishable flame, reverenced the profound ancestral song, and one by one arose in homage to extramundane intelligence" (353). Music destroys chaos and creates cosmos: "Thus Nereus can know the limits of the seas, and the fiery bodies of the sky can draw nourishment, so that dissonant elements may not teem with strife, that parts remote may cherish lasting bonds and always dread the ruptive forces of Chaos. Ruler of the heavens, best Father, gathering the stars in fond embrace, you quicken your offspring with eternal bodies. Hail! For you our lyre is attuned, for you the gamut of our song resounds in double diaspason" (354). The heavenly figures and humans join in the creation of music because it sets up the foundation for all existence. Even the gods have to yield to the force of music, which Martianus characterizes as the elemental power of the universe: "Harmony's songs delighted and soothed the spirits of all the gods; and the strains that poured forth from her stringed instruments were no less sweet than the melody of her voice" (356). In fact, Harmony identifies herself as "the twin sister of heaven" (356).

As we will learn subsequently also from Boethius, music represents the celestial geometry: "It was I who designated the numerical ratios of perceptible motions and the impulses of perfect will, introducing restraint and harmony into all things" (357). From this resulted, at the time of origin, "a universal law for all mankind" (357). Insofar as Harmony revealed her art to the representatives of Delphi, the divine power of music became shared with all people who were thus entitled to engage with the gods and to fend off the underworld: "Through me, in fact, men have inveighed the support of you deities and have quelled the anger of the underworld deities through mournful songs" (357). Both war and peace have become determined by music, and the soothing influence of music affected the raging and mad crowds or insane individuals (358). Significantly, as we also learn, the ancients were capable of using music for medical treatments: "Is anyone unaware that gout in the hip is removed by the sweet tones of the aulos? " (358) (Mishra; Klinksiek; Jacobsen, Nygaard Pedersen and Bonde, ed.). xiii Significantly, music is also identified as a sensory force affecting animals: "It is a fact Indian elephants are restrained by the soothing effects of musical instruments; it is also common knowledge that birds are attracted by reed pipes and that rattles pacify crying infants" (359).xiv For this late antique author, then, music emerges as a universal language that can be understood, with differing degrees, by humans and animals, a phenomenon which had already been described by the ancient Greek myth of the extraordinary musician and poet Orpheus who could appeal to all things and living creatures (Butler and Bassler, ed. for the concrete historical figure and its reception throughout time, see https://en.wikipedia.org/wiki/Orpheus; last accessed on June 17, 2021). ${ }^{x v}$ Even spirits and the moon are said to be open to the impact of music as the universal language of all material and spiritual existence (359). The subsequent section of the treatise De nuptiis Philologiae et Mercurii engages with many technical aspects of music, which subsequent scholars elaborated further. What remains, then, is the realization that Martianus can be credited with having laid the foundation of music harmony for centuries to come, and 
although we do not know whether he exerted influence also outside of the western world, we can be certain that the universal notions of music as defined by him might continue to matter in transcultural terms among all cultures and peoples even today

Martianus lost somewhat in influence by the end of the twelfth century when Aristotelianism entered university studies, but the division into the seven liberal arts remained fundamental for all advanced learning throughout the entire Middle Ages, as was beautifully illustrated, for instance, by the Hortus Deliciarum of Herrad of Landsberg (ca. 1180) (Abelson; Wagner; Lindgren). Most remarkable for our purpose, above all, proved to be the great emphasis on music as the secret language of the stars and planets which was regarded as divine in essence.

Music was also one of the central topics by Boethius (d. ca. 524), who composed the highly influential treatise De institutione musica (at least 137 medieval manuscripts from the ninth to the fifteenth centuries) and endeavored to translate the basic teachings of music by the Greeks. He analyzed the various types of music, identifying three types of modalities: Musica mundana, Musica humana, and Musica instrumentalis. Whereas the first was the music of all of cosmos, hardly perceptible but the basic rhythm of all existence, the second was music created by people who thus established a spiritual harmony with the divine, and the third was the music created by instruments (Boethius 1989). Boethius was not so much concerned with the practical or theoretical aspects of music in its performative character, but with the meaning and our understanding of music as a fundamental phenomenon in human life revealing truth about this world on the micro- and macrocosmic level. We could thus identify Boethius's approach to music as epistemological, which subsequently fit well with the concept of music as embraced by the Catholic Church as the largest cultural entity during the entire Middle Ages.

Even though Boethius was not necessarily an innovative thinker, and served rather as a mediator between Greek and Roman culture, hence also as a translator and philologist, his contributions to the discourse on music shaped much of the future understanding of this phenomenon.

As he emphasized, "For nothing is more characteristic of human nature than to be soothed by pleasant modes or disturbed by their opposites" (I, 179, p. 2). Through voluntary action, music activates the senses of all people who are thus brought together within a universal community: "Indeed, music extends to every endeavor" (ibid.). Music mirrors the individual's character and nature, so we could apply this Boethian notion and adapt it to this proverb: tell me what music you listen to, and I am going to tell you who you are: "A people finds pleasure in modes because of likeness to its own character" (I, 180, p. 3). Referring to Plato, Boethius emphasizes that music influences and shapes the individual mind, which ultimately would determine the collective attitudes and values. 
When the predominant music develops a rough character, then public culture changes accordingly, or vice versa, an idea which might have some correlations with the situation in the twenty-first century (mass shootings, high crime rate, heavy use of drugs, domestic violence, etc.), at least in the western world. According to Plato, as Boethius observes, "there is no greater ruin of morals in a republic than the gradual perversion of chaste and temperate music" (ibid.). Songs, in particular, have exerted a calming effect on troubled minds, as can be observed well until today especially in Hawaiian music, which stands in radical contrast to Hard and Metal Rock. After all, music and culture interact with each other intimately, so Boethius's ideas deserve to be considered more closely also today since the postmodern world is undergoing such striking transformations, whether to the better or the worse should not be decided here (Sulzer; Kirmayer, Worthman, Kitayama, and Lemelson, ed.; Mukherji).

Drawing from many different classical examples, Boethius emphasizes how much music determines our sleep, our daily activities, and our moods and mindsets. Without fully revealing the nature of his observation, the author nevertheless underscores the intricate relationship between music and the human soul, and those again in direct relationship with cosmos: "If a certain harmony did not join the diversities and opposing forces of the four elements, how would it be possible that they could unite in one mass and contrivance" (I, 188, p. 9).

There is always harmony, contained in the human body and mind, and hence also in nature, so the study of music facilitates the exploration of all of existence being in unison and communicating with each other fully, whether we perceive it directly or not. But music proves to be the bond between the individual and the universe, so it elevates even the most simple-minded individual to the highest spiritual levels, even if s/he has only an inkling of the esoteric relevance of music listen to or performed. But Boethius does not think so much about the musician him/herself; rather, he is primarily concerned with the interaction between music and the individual, that is, his/her soul. Hence, he does not concern himself much with the practical performance, and instead underscores "the study of music as a rational discipline" (I, 224, p. 50). And: "How much nobler, then, is the study of music as a rational discipline than as composition and performance! It is as much nobler as the mind is superior to the body" (ibid.).

Apart from many detailed and technical aspects relevant for music, Boethius focuses primarily on harmony as the ultimate outcome of music, being an instrument to connect the soul with the cosmos, if not the individual with the Godhead. As Boethius claimed at the very beginning, music is associated with truth and morality $(\mathrm{I}, 179, \mathrm{p} .2)$, and it has pleased people of all ages throughout time (I, 186, p. 8). The critical study of music, however, quickly leads over to mathematical calculations which pertain not only to the pitch, the tonality, and time, but also to the awareness of cosmic relations which find 
their analogies in all material conditions: "If all things were at rest, no sound would strike the hearing; such would be the case, because, with the cessation of all motion, objects would effect no pulsation among themselves" (IV, 301, p. 115). The final goal consists of realizing the "harmonic rule." Following Ptolemy, Boethius highlights that it is achieved when "there is nothing irreconcilable between the ears and reason. . . reason searches out ratios to which the sense expresses no objection" (V, 355, p. 165) (Chadwick; Heilmann).

From here we could jump to the world of Gregorian chant practiced in monasteries and cathedrals throughout the Middle Ages, we could study the famous hymns by the magistra and mystic Hildegard of Bingen (1098-1179) (Hildegard of Bingen; Scherer), take into consideration the teachings by such luminaries as Gregory of Nazianzus (ca. 339390), John Chrysostom (ca. 347-407), Gregory the Great (540-604), by late medieval mystics such as Mechthild of Magdeburg (ca. 1207-ca. 1284), Henry Suso (in German: Heinrich Seuse; 1295-1366) and Richard Rolle (1300-1349), and from there aim for worldly music which emerged at the many different secular courts across medieval Europe since the early twelfth century (Heller). ${ }^{\text {xvi }}$

Music, of course, had also been performed at earlier times, and then mostly in heroic contexts (bards), as we can hear regularly in the anonymous Beowulf, for instance. However, the emergence of courtly culture was intimately associated with the rise of courtly love song accompanied by the harp, the lyre, or the fiddle (Kügle; Diehrl; McGlathery, ed.). This phenomenon is expressed probably most poignantly by one of the greatest courtly romances crucially predicated on music as the unique charm which the protagonist employs throughout his life, and which connects him both with the highest echelons of society and with his future love. Their love appears almost as a new religion, if we consider particularly the prologue, so, to rephrase my initial hypothesis, music does not only connect the individual with the divine, it also creates if this is not almost a tautology, love, or it is a form of love in aesthetic terms. Music leads to love, and love leads to God, as we might claim in a somewhat speculative way. The next section will shed specific light on this phenomenon.

\section{Gottfried von Strassburg, Tristan}

The greatest representative of this new music was Tristan, especially in the version developed by Gottfried von Strassburg (ca. 1210). We do not learn too much about the theoretical and practical aspects of his singing and playing of musical instruments, but it is entirely evident that this protagonist commands the highest level of musical education and can play virtually all instruments presented to him basically to perfection (Gottfried von Strassburg; cf. Chinca; Tomasek). His musical art is so sophisticated that the young protagonist entirely charms the court of King Mark of Cornwall; all of its members are not 
only excited but almost delirious and regard the young man as charismatic who can transform their own existence into something more esoteric by means of his music (Jaeger). As research has noted already numerous times, the protagonist as a musician emerges as a new King David, creating miracles with his harp and other instruments. Music is thus identified as a medium of magical, or spiritual, power which enables Tristan to excel at King Mark's court, to transform that world and to elevate it to a higher level (Kästner).

Later, Tristan uses his music to deceive some of his opponents, such as the Irish queen Isolde who wants him to teach her daughter Isolde the fine secrets of his art. Since the young princess is already so highly developed as a musician, Tristan's teachings prove to be just the final touches, and through her singing and playing music she subsequently knows how to bedazzle the entire court in Ireland, just as Tristan had done in Cornwall. Since this romance treats the love affair between these two people as a matter of life and death - though not in the Romantic fashion as developed by Richard Wagner in his opera Tristan und Isolde, first performed in 1865, and formulated by Denis de Rougemont in his famous but highly speculative essay L'Amour et l'Occident (1939; reprinted many times thereafter) (Classen 2020) - it is no wonder that they have found each other already early on via music, though their love truly blooms not until later when Tristan wins her hand on behalf of his uncle, King Mark of Cornwall.

At the end of the romance, however, when Tristan tries to console the young woman and sends her the magical dog Petitcreiu, Isolde is not at all pleased with the music associated with it. The dog carries a chain around its neck to which is attached a small bell, the music of which works like a magical charm, injecting into everyone who listens to it an artificial form of happiness. Isolde soon realizes the danger to her feelings of true love for Tristan, so she destroys the bell and hence the music. Indeed, she does not want to be drugged musically into a false sense of happiness without Tristan, and consequently, she pulls off the bell and thus destroys the

seemingly utopian music. This allows her to stay true to her feelings of love, whereas the music would have injected a fall sense of joy into her heart.

Finally, in the penultimate episode, when the two lovers have been expelled from court because their erotic transgression has become too obvious and intolerable to the king, the couple retires into a love cave where they can spend all their time enjoying each other without any concerns for material conditions. They no longer need to eat, and they go hunting only for entertainment. They tell each other stories of famous lovers, and play music together, which altogether creates an idyllic setting for them, which justifies us to call this cave or grotto a utopia of love (Tomasek 1985; Richardson). Of course, like in the case of every other utopia (political, social, or erotic), their stay is limited, as they ultimately 
desire to return to society and enjoy their public reputation (honor) there. When King Mark appears by accident and discovers the couple sleeping in the cave - he is gazing down into the cave looking through one of three little holes in the ceiling - he is deceived by a sword that Tristan had placed between himself and Isolde as a fake indicator that they are not lovers. Since Mark is deeply in love with his wife Isolde and also profoundly appreciates his nephew Tristan, he allows them to return to his court, though he requests from them to control their eyes and stop looking at each other so intensively and lovingly. This is, however, not possible for the two protagonists, and soon enough, Mark discovers them in flagrante, which forces Tristan to depart for good, while leaving grieving Isolde behind.

This means not only that their love affair is disrupted, but also that their musical harmony has come to an end. Tristan subsequently comes across another Isolde, Whitehand, and he performs his extraordinary music in her presence, singing love songs dedicated to Isolde, but he only confuses the poor woman who believes that he might mean him, whereas he is really thinking only about the Irish princess. The music that used to bond the two lovers is no longer expressing the traditional harmony, whether Tristan still upholds his original love or not. We remember now that he had already misused music by winning the magical dog Petitcreiu with its music from out of this world which creates a false sense of happiness in the listener. Of course, he had wanted his Isolde to experience joy and happiness, but she could not tolerate the idea of being free of sorrow without Tristan in her presence. Even though Isolde is passionate about music, which she identifies, in a way, with her love for Tristan, she ultimately rejects artificial music which does not come from her own heart, and prefers her suffering as the true expression of her love. Music is possible for Isolde when she is together with Tristan, but she cannot stand the idea of music when it is not associated with her lover or produced by him or her.

Gottfried thus reaches several conclusions regarding music. At first, it ennobles the individual and connects him/her with the divine, as the various audiences in Cornwall and Ireland clearly recognize. Music establishes the initial bond between the future lovers, but once love has bloomed, we do not hear about them performing music together while spending time within courtly society. They both resort to music only when they are expelled from the court and have found their refuge in the love cave. When far away from the world, the voice of music becomes audible again and plays out their pure love for each other. However, this kind of music is always only of a temporary kind because it is the magic that connects the individual with love, that is, the divine. This makes perfect sense also in the way how Martianus and Boethius had outlined it because music is determined by the notion of time and the interaction of two individuals or objects in a cosmic context.

\section{Music and the Early Modern Protagonist}


This topic could be pursued throughout the entire Middle Ages and well beyond. In the famous and pan-European collection of tales, Historia septem sapientum (prior to 1342), also rendered as Dolopathos in Old French and as Die Historia von den sieben weisen Meistern (ca. 1460) in late medieval German, in one story (no. XIII, "Inclusa"), two lovers find themselves by accident by means of music after they had dreamed about each other. As soon as he has recognized her, stuck in a prison tower where her husband keeps her safely for himself, he begins to sing a song about love, which alerts her to him standing below her in the street, which ultimately makes it possible for both to come together (Steinmetz, ed., no. XIII, "Inclusa," 47-48). In another story ("XII, "Amatores"), a woman sings so sweetly that three knights madly fall in love with her and are so transfixed by her that they are immediately prepared to carry out her demands in return for her love (sex). She is, however, loyal to her husband and arranges with him to get the knights' money and kill each of them.

Finally, let us conclude with a few comments on a major sixteenth-century German novel by Jörg Wickram, Der Goldfaden (1557; The Golden Thread), in which music, i.e., the young protagonist Lionel's singing, matters centrally to elevate him from his low social status as a kitchen boy to being a page serving in the women's quarters. xvii Since the young man entertains all the retainers at court so much with his singing of "many and diverse ballads of chivalry" (15), he receives many gifts and can thus afford elegant clothing. He soon falls in love with the count's daughter Angeline, but it takes quite some time until she realizes that and then soon after returns his feelings, which creates considerable social tensions.

When Angeline ignores Lionel once at New Year's Day and does not hand him a gift like she does for all other retainers, he feels deeply hurt and soon expresses his sorrow in a newly composed song, which he must perform to all the maids and their mistress. While the other women simply enjoy this song without understanding the secret message, Angeline quickly realizes her page's true feelings hidden in the song, which then has a deep impact on her emotionally. She then grants him as a gift a golden thread, which explains the title for this novel, which he secretly sows into his own flesh in her honor, and then sings about this: "He surmised that since Lady Angeline had seen through his other ditty so well, she would also ponder this one" (25). Later, she has to observe his cruel selftreatment, cutting open the same incision and removing the thread to return it to her, which thus serves as final proof of his unwavering love for her. Both through his selfless actions and his singing thus blazed a path into her heart, and soon enough the story itself takes off with a long narrative sequence tracing Lionel's efforts to survive dangerous situations, to prove himself to his beloved, and ultimately to turn into a knight, which then also makes it possible for him to marry Angeline and subsequently to succeed his deceased father-in-law to the throne. 
Wickram underscores with great care the aesthetic appeal of the young man's singing: "he was singing with a voice so clear and lovely that the birds could not help answering him with their own song" (17). When the count first realizes that this kitchen boy commands such a superb voice, he immediately promotes him: "'You should be able to enjoy your voice and your good singing and have another and better office than you have now" (18). Music is thus identified as the gateway for Lionel's miraculous rise from the lowest social level to the very highest, especially because it makes possible that his dream of Angeline's love can be realized. As we learn: "Lady Angelin, in the meantime, had found out that Lionel was the very youth who was singing in the garden. Therefore, she was particularly pleased that Lionel was to enter her service. Her maidens rejoiced no less, for they hoped that from time to time Lionel would entertain and muse them with his singing" (19). Music goes through the heart and ultimately creates the spiritual and emotional unity which represents the foundation for the love between these two young people. The parallels with Gottfried's Tristan are quite striking, though Lionel does not play any music instrument and excels 'only' through his voice. By creating a musical bond with his beloved, he bridges the physical distance and creates a new, erotically founded form of harmony, a phenomenon which has probably been shared across the world and throughout times in countless different manifestations.

\section{Conclusion}

This allows me to turn to yet another example, though not medieval, as the final illustration where music emerges as the ultimate medium to establish happiness, hope, love, and friendship, all virtues, which in turn reflect on the music or are made possible through the delight, if not delirium, of some of the best music ever created. Ludwig van Beethoven, in his final symphony, the Ninth, in D minor, Op. 125, composed between 1822 and 1822, drew from Friedrich Schiller's famous "Ode to Joy" written in 1785 and revised in 1803, along with his own textual additions. This amazing piece of music is performed until today all over the world and is often recognized as the virtual anthem of the global community. While the main argument here pertains to the role of music, the lyrics deserve particular attention since they underscore the universal, transcultural component so powerfully. One stanza, for instance, illustrates the global perspective projected here through sound and words:

Whoever has been lucky enough

to become a friend to a friend,

Whoever has found a beloved wife,

let him join our songs of praise!

Yes, and anyone who can call one soul

his own on this earth! 
Any who cannot, let them slink away

from this gathering in tears!

Insofar as the symphony addresses joy and love, it is no wonder that this master symphony by Beethoven has appealed to audiences across the world. The spiritual concept behind it proves to be absolutely transcultural and represents maybe the greatest expression in music and poetry of humanity as being one large family:

Be embraced, you millions!

This kiss is for the whole world!

Brothers, above the canopy of stars

must dwell a loving father.

As a result of this global appeal, in 1972, the musical part was adopted as the anthem of Europe by the Council of Europe and subsequently by the European Communities (now the European Union) in 1985. Beethoven's Ninth Symphony is performed all over the world today, especially in Japan where it was introduced by German prisoners of war during World War I, but also in Rhodesia, today Zimbabwe, where the final sequence was performed as the national anthem between 1974 and 1979 (Eichhorn; Levy). xviii The Seattle Symphony Orchestra plays Beethoven's work every year on New Year's Eve since 1999. The Greek-Russian conductor Teodor Currentzis is quoted regarding this symphony as follows: 'If somebody from another planet asks, 'What is human civilization?' what can you say? It's better to play the 9th Symphony. It is evidence of human civilization." xix

Where does all this leave us then? Can we establish connections between Martianus Capella, Boethius, Beethoven, and The Beatles? I have not said anything really about Hip Hop, or Jazz, Korean ballads, Native American flute music, or Peruvian Música criolla and Huayno, and we could add a virtually infinite list of other manifestations of music from all over the world, music performed in the streets, on the radio and TV stations, in orchestra houses, in private and in public to explore this issue further. But whatever other types of music we might mention, the ultimate understanding of the meaning of music in global terms would not change essentially.

Granted, music can and has been abused by many different powers throughout history. But music has always served also as an abstract protest against political repression and dictatorship. On an individual level, music creates joy and happiness, and it establishes identity and culture, while it can also bring about sorrow, melancholy, and sadness, depending on the circumstances, but always resonating with our human soul, so to speak. As we have learned particularly from late antique philosophers, in the premodern world music constituted a cosmic harmony, or leads us to an understanding of the world in spiritual terms, and I would suggest that we today can profoundly profit from such concepts about music once again if we regain and accept those spiritual and 
philosophical notions as valid particularly in the appreciation of music. Every generation, every culture, every social class, every gender and race produces its own music, although musical appreciation knows no bounds or limitations. Of course, western listeners not need much preparation to enjoy and appreciate eastern music, and vice versa, particularly there are always deeper levels of meaning which only closer study would make accessible. Yet, we can certainly agree that the events with the Tower of Babel in the Old Testament - the creation of many different languages to stop the further rebellious construction did not affect music, so we continue today to 'speak' to each other across all linguistic and cultural boundaries in musical terms, and this without much need for translators.

This is not to say that music does not have to be studied carefully to gain deeper insights into its structural elements and cultural framework, into its meaning and relevance. But much music from across the world proves to be open to universal comprehension, addressing emotions, ideas, ideals, values, spirituality, and also concepts. Little wonder hence that especially German and Austrian Classical music from the late eighteenth and early nineteenth century, late nineteenth century post-Romantic Polish or Czech music, or Peer Gynt by the Norwegian composer Edvard Grieg (1875), or the impressionist compositions by Claude Debussy (1862-1918) continue to haunt the human mind and soul all over the world. There are, of course, many local musical traditions, folkloric approaches, and unique tonalities which separate, say, Chinese from Indian music, and I wonder to what extent western listeners have responded to those Asian or African contributions to music in a meaningful way. Nevertheless, music emerges as a transcultural experience that knows no historical limitations, which has allowed recent musicologists to go so far as to compare early-medieval Carolingian neumes with ninthcentury Buddhistic Pipa scale (Klein 173-82). For that reason, the critical comments by Martianus Capella and Boethius matter so much for us until today insofar as they laid the foundation for universal, cosmic music. Although the music performed with the didgeridoo by the aborigines of northern Australia at least already for the last 1,500 years seems to be far away from all those insights and approaches, ultimately that music pursues apparently the very same purpose of connecting the individual with the universe. ${ }^{\mathrm{xx}}$ Music offers the great opportunity to speak a global language and to connect with all people here on earth.

I would like to conclude this essay with a few references to the famous novel, The Glass Bead Game, by the German novelist Hermann Hesse. It was published in 1943 and won Hesse the Nobel Prize for Literature in 1946 (Hesse. There are many valuable critical studies on this novel; see, for instance, Roberts). In essence, this glass bead game involves the intricate combination of many different intellectual and aesthetic aspects, eastern religion, Japanese music, and mathematics, for instance (Bruhn). The master of the game, Joseph Knecht, conceives, as his last act of performance, the notion of using the "ancient 
ritual Confucian pattern for the building of a Chinese house; orientation by the points of the compass, the gates, the spirit wall, the relationships and functions of buildings and courtyards, their co-ordination with the constellations, the calendar and family life, and the symbolism and stylistic principles of the garden" (145). Although in this case music does not play a significant role, throughout the quasi-monastic community music matters centrally, but neither in the actual Glass Bead Game nor in any other ceremonies can Knecht really find meaning and relevance, which is, however, not a criticism of music, but a criticism of elitist and too abstract culture without any social commitments and obligations.

He ultimately leaves the community of Castalia to enter the service of being the private tutor of his best friend's son, Tito, but he dies in that effort drowning in an icycold alpine lake, yet not without leaving behind an impact on this young person, whose life becomes transformed because of Knecht's death. While Knecht at the end fails and rejects the community, he finds a new way back to real life, as a teacher, though he has to die in that process. As we learn in the early part of the novel, music might be the only medium, apart from poetry and sculpture, to express the meaning of death and to point out the way toward a new existence. We do not hear Knecht playing music at the end, but his entire education was intimately tied in with music. Music such as Johann Sebastian Bach's fugues represents some of the critical tools to play this ritual game, in which all cultures of the world come together to create new harmony. The earliest encounter with one of the Masters of the Community of Castalia conveyed that discovery most vividly:

His ear drank in the fugue, it seemed to him that he was hearing music for the first time in his life. Behind the music being created in his presence he sensed the world of Mind, the joy-giving harmony of law and freedom, of service and rule. He surrendered himself, and vowed to serve that world and this Master. In those few minutes he saw himself and his life, saw the whole cosmos guided, ordered, and interpreted by the spirit of music. (55).

Thomas Mann (1875-1955) also emphasized the role of music for the emergence of the post-modern world in his novel Dr. Faustus (1947), the story of the composer Adrian Leverkühn, and in that context similarly formulated severe criticism of the contemporary world which would require a profound innovation and transformation especially by means of music, as expressed early on by the new musical compositions created by the German spiritualist Conrad Beissel (1691-1768), the leader of the religious community of Ephrata in Lancaster County, Pennsylvania. However, Leverkühn, modeled after Arnold Schönberg and also Friedrich Nietzsche, is identified as the inventor of the twelve-tone music, a genius new form of abstract music. Nevertheless, this invention proves to be the result of his contract with the devil, and it leads to his early death. It remains a matter of debate whether Mann tried to express his admiration or contempt of this new musical strategy, 
but whatever perspective we might pursue in our analysis, we can be certain that this great author deeply appreciated and acknowledged the existential power of music in the lives of all people (Vaget; Savietto).

But we could and should move back and forth and across the continents and cultures and confirm consistently the crucial relevance of music, the evanescent language of highest esoteric quality, and epistemological challenge of the highest order characterizing human life as such.

Even a child's song or simple ditties from anywhere in the world resonate this secret and thereby participates in the continuous search for identity in the cosmic spheres. In this regard, we must incorporate the critical voices from the Middle Ages (Martianus, Boethius, Hildegard of Bingen, Gottfried von Strassburg) and beyond (Jörg Wickram) in our ongoing investigation of the meaning of human life within the universal context, past and present.

Music in itself does not know time limits, geographical boundaries, class distinctions, race differences, or gender issues. Music sings in our souls, it elevates us out of our material limitations, and it provides us with joy, melancholy, hope, and excitement, and thus it constitutes the critical springboard for spiritual explorations both of our soul and our body. We create music in order to reach the inner levels of our existence, and it comes to us as a message from the soul. I have mentioned above also the negative, dangerous sides of music, as a manipulative force, but everything aesthetic and spiritual can be abused, whereas it is our task as the recipients to recognize the deeper value and meaning of music, for instance, and make the best out of this esoteric experience transforming ourselves in the process of listening, or playing ourselves.

Not everyone can understand or appreciate every kind of music from all time periods, but it is one of the basic human features to enjoy music and to learn its language because of the rhythm, melodiousness, harmony, and sonance. Although I have not addressed enough non-western music in this paper, as I have to admit, due to my own cultural limitations, we can certainly agree that music in international and intercultural terms matters centrally for all humanity. Even though every country has its own national anthem, they are all surprisingly bonded together through their intention of providing a musical representation for the entire people. Every anthem carries profound values and ideals, whether they are considered honestly or for ideological purposes only.

For that reason, music created with the digeridoo or with the medieval hurdy-gurdy can certainly resonate with every individual here on earth. In that regard, the comments by Martianus Capella and Boethius prove to be relevant for us as well, and this after ca. 1500 years, because they addressed already and most insightfully the ultimate and 
deepest character, purpose, and meaning of music in universal and harmonic terms. Appreciation of music is more than just an aesthetic experience; instead, here we encounter an epistemological phenomenon which proves to be fundamental for all human culture and identity. We might want to go so far as to claim that music is the aesthetic expression of our hearts and minds, hence of our humanity in the first place. Little wonder that many religious perspectives are intimately associated with music, whether played by angels or the gods themselves. $x \times i$

\section{Notes}

i. From a modern perspective, see the contributions to Feiereisen and Hill, especially their introduction with many references to other recent studies on soundscapes, 1-14. As they observe, "One of the main qualities of all-scapes, including soundscapes, is their fluid character. Soundscapes are always changing, every second is different" (10); cf. also the fundamental studies collected in Kruth and Stobart, ed.

ii. See also the contribution by Goebel to the present volume, exploring more in detail the concept of music as embraced by the Romantics such as Wilhelm Heinrich Wackenroder and modern writers such as Franz Kafka and even Haruki Murakami. I would like to acknowledge his inspiration for this paper, and his comments on an early draft.

iii. https://en.wikipedia.org/wiki/Traditional_Japanese_music (last accessed on Sept. 23, 2021).

iv. https://en.wikipedia.org/wiki/Music_of_Ethiopia (last accessed on Sept. 23, 2021).

v. https://en.wikipedia.org/wiki/Music_of_India (last accessed on Sept. 23, 2021). Since I cannot claim to be an expert in all of those musical areas, these references to Wikipedia article may suffice; similar information can be found, of course, in The New Grove or in Musik in Geschichte und Gegenwart.

vi https://www.youtube.com/watch?v=ZfRkJjwEzCs. There are many other similar cases, such as the version for guitar by George Chatzopoulos; https://www.youtube.com/watch?v=d9ms6mj4sX4; see also his version of Johann Sebastian Bach's JFugue BWV1000, https://www.youtube.com/channel/UCrdYE7rDU7OwDSPqIB0zCuA (all three last accessed on Sept. 23, 2021).

vii. For a good overview, see https://en.wikipedia.org/wiki/Atonality (last accessed on Sept. 23, 2021).

viii. This topic is much discussed in printed form and online; see, for instance, https://www.zerotothree.org/resources/1514-beyond-twinkle-twinkle-using-music-with-infantsand-toddlers (last accessed on Sept. 23, 2021). 
ix. See also the blog site "Decolonizing Classical Music: Future of Black German Musicians | FUBEST \& FUBiS Lecture Series," July 2021, online at: https://www.youtube.com/watch?v=2K9SUbwY7fI. Of interest would also be Brown.

x. For an interesting exception, see Sergej Prokofiev's "Peter and the Wolf" from 1937 or the "Toy Symphony" possibly by Leopold Mozart from the 1760s ("Cassation in G major for toys, 2 oboes, 2 horns, strings and continuo).

xi. Quoted from https://en.wikipedia.org/wiki/Les_pr\%C3\%A9ludes; see also https://military.wikia.org/wiki/Wehrmachtbericht (both last accessed on June 13, 2021).

xii. Steiner; cf. https://www.oxfordhandbooks.com/view/10.1093/oxfordhb/9780199639755.001.0001/oxfordhb -9780199639755-e-3 (last accessed on June 15, 2021).

xiii. There is a surging medical field called 'music therapy' which demonstrates amazing results. On one website we are informed, for instance, that "Heart rate, blood pressure, and oxygen consumption decrease when the right type of music is played. This auditory stimulus positively affects the patient physiologically and psychologically," https://journals.Iww.com/nursingcriticalcare/fulltext/2014/11000/music_helps_heal_mind,_body, and_spirit.6.aspx; see also https://www.healthline.com/health/sound-healing\#types; or https://www.health.harvard.edu/blog/healing-through-music-201511058556 (all last accessed on Sept. 23, 2021).

xiv. The same phenomenon was explored in the 2003 German docudrama "The Story of the Weeping Camel," internationally released in 2004, directed and written by Byambasuren Davaa and Luigi Falorni. A female camel does not bond with its newborn white calf and denies it her milk. After many trials and efforts, a local violinist is called in who performs a ritual folk song that ultimately charms the camel so much that it starts to weep, loosening up its emotional blockage. Thereafter, the calf is allowed to drink the mother's milk and is thus saved. https://en.wikipedia.org/wiki/The_Story_of_the_Weeping_Camel\#Plot; https://www.imdb.com/title/tt0373861/ (both last accessed on Sept. 23, 2021).

$x v$. For the concrete historical figure and its reception throughout time, see https://en.wikipedia.org/wiki/Orpheus (last accessed on Sept. 23, 2021).

xvi. Mechthild of Magdeburg, Book I, 6, p. 45: "We praise you, Lord, that you sought us in your humility. / We praise you, Lord, that you have kept us in your mercy. / We praise you, Lord, that you have glorified us in your humiliation ...." The vocalization of the spiritual outreach to the Godhead proves to be one of the key aspects of music all by itself.

xvii. Wickram; for an excellent biographical and interpretive study, see Kleinschmidt; as to the central topic of the rise of the poor protagonist from the social class of herdsmen to the rank of count, see Lee. 
xviii. For a convenient, and also very comprehensive coverage, see, for instance, https://de.wikipedia.org/wiki/9._Sinfonie_(Beethoven)\#National__und_Europahymne; https://en.wikipedia.org/wiki/Symphony_No._9_(Beethoven) (both last accessed on Sept. 23, 2021). Zimbabwe's national anthem is a very different one today, of course; https://en.wikipedia.org/wiki/National_Anthem_of_Zimbabwe (last accessed on Sept. 23, 2021).

xix. https://www.dw.com/en/beethovens-ninth-symphony-for-the-world/a-52625691 (last accessed on Sept. 23, 2021), with data on other performances globally in recent times. See also Mercer-Taylor.

xx.https://en.wikipedia.org/wiki/Didgeridoo\#Cultural_significance; https://www.aboriginalart.com.au/didgeridoo/what_is.html (both last accessed on Sept. 23, 2021).

xxi. Boyce-Tillman 2018; Nielson. I was not yet able to consult this new study, but it promises to point toward a global perspective regarding the universal value of music in all cultures throughout time. In the abstract posted by the publisher, we read: "the book sheds light onto the dynamics of medieval Islamicate courts, as well as how slavery, gender, status and religion intersected with music in courtly life. It will appeal to scholars of the Islamicate world and historical musicologists" (https://kvk.bibliothek.kit.edu/viewtitle/index.php?katalog=BVB\&url=https\%3A\%2F\%2Fwww.gatewaybayern.de\%2FBV047351148\&signature=Bu-XVyNjkOryXRLeGoLtSK-dEzyMSeW3TKw4wcyS2g\&showCoverImg=1; last accessed on Sept. 23, 2021). Undoubtedly, we could make very similar observations regarding music in Indian, Russian, Congolese, or Australian cultures.

\section{References}

Abelson, P. (1906/1965). The Seven Liberal Arts: A Study in Mediaeval Culture. Contributions to Education, 11. New York: Russell \& Russell.

Aitken, J. (2007). John Newton: From Disgrace to Amazing Grac. London: Continuum.

Baumann, M. P. (Ed.) (2002). Body and Ritual in Buddhist Musical Culture, ed. Max Peter Baumann. The World of Music, 44.2. Berlin: VWB, Verlag für Wissenschaft und Bildung.

Boethius (1989). Anicius Manlius Severinus Boethiis, Fundamentals of Music, trans., with Intro. and Notes by C. M. Bower, ed. C. V. Palsca. Music Theory Translation Series. New Haven, CT, and London: Yale University Press.

Boyce-Tillman, J. (2018). Freedom Song: Faith, Abuse, Music and Spirituality: A Lived Experience of Celebration. Oxford, Bern, et al.: Peter Lang.

Boyce-Tillman, J. (Ed.) (2017). Spirituality and Music Education: Perspectives from Three Continents, ed. June Boyce-Tillman. Music and Spirituality, 5. Oxford, Bern, et al.: Peter Lang. 
Boyce-Tillman, J., S. B. Roberts, and J. Erricker (Ed.) (2019). Enlivening Faith: Music, Spirituality and Christian Theology. Music and Spirituality, 9. Oxford, Bern, and Berlin: Peter Lang.

Brown, J. (2021). Black Utopias:Speculative Life and the Music of Other Worlds. Durham, NC, and London: Duke University Press.

Bruhn, S. (2005). The Musical Order of the World: Kepler, Hesse, Hindemith. Interplay, 4. Hillsdale, NY: Pendragon Press.

Burdorf Lautenbach, H. (2006). Liedermacher des Mittelalters: Minnesang. Frankfurt a. M.: FouquéLiteraturverlag, 2006).

Butler, K., and S. Bassler (Ed.) (2019). Music, Myth and Story in Medieval and Early Modern Culture. Studies in Medieval and Renaissance Music, 19. Woodbridge, Suffolk: Boydell \& Brewer.

Chadwick, H. (1981). Boethius: The Consolations of Music, Logic, Theology and Philosophy. Oxford: Clarendon Press.

Chinca, M. (1997). Gottfried von Strassburg: Tristan. Landmarks of World Literature. Cambridge: Cambridge University Press.

Classen, A. (2020). "Denis de Rougemont: Erforscher des Tristan-Mythos und Begründer eines neuen Liebes- und Todes-Mythos," tristan mythos maschine 20. jahrhundert ff., ed. R. Schoeller and A. Schindler, with the collaboration by P. Bannwart, N. Busch, and M. Dallapiazza. Rezeptionskulturen in Literature- und Mediengeschichte, 16. Würzburg: Königshausen \& Neumann, 47-65.

Classen, A. (Ed.) (2019). Paradigm Shifts during the Global Middle Ages and the Renaissance. Arizona Studies in the Middle Ages and the Renaissance, 44. Turnhout: Brepols.

Classen, A. (forthcoming). "Soundscapes in Medieval German Literature," to appear in $A$ Companion to Sound Studies in German-Speaking Cultures, ed. R. Goebel. Rochester, NY: Camden House.

Coward, H. (2019). Word, Chant, and Song: Spiritual Transformation in Hinduism, Buddhism, Islam, and Sikhism. SUNY Series in Religious Studies. Albany, NY: State University of New York Press.

Diehr, A. (2004). Literatur und Musik im Mittelalter: Eine Einführung. Berlin: Erich Schmidt.

Eichhorn, A. (1993). Beethovens neunte Symphonie: die Geschichte ihrer Aufführung und Rezeption. Kasseler Schriften zur Musik, 3. Kassel: Bärenreiter.

Fackler, G. (2007). "Music in Concentration Camps 1933-1945," trans. from the German by P. Logan, Music \& Politics 1.1, online at: https://doi.org/10.3998/mp.9460447.0001.102. 
Feiereisen, F. and A. M. Hill (Ed.) (2012). German in the Loud Twentieth Century: An Introduction. Oxford: Oxford University Press.

Gallope, M. (2017). Deep Refrains: Music, Philosophy, and the Ineffable. Chicago and London: The University of Chicago Press.

Gottfried von Strassburg (1960/1967). Tristan. With the surviving fragments of the Tristran of Thomas. With an intro. by A. T. Hatto. London: Penguin.

Gottfried von Strassburg (1980). Tristan, ed. and trans. R. Krohn. Stuttgart: Philipp Reclam jun.

Grebe, S. (1999). Martianus Capella - De nuptiis Philologiae et Mercurii : Darstellung der Sieben Freien Künste und ihrer Beziehungen zueinander. Beiträge zur Altertumskunde, 119. Stuttgart: Teubner.

Gülke, P. (1998). Mönche, Bürger, Minnesänger: die Musik in der Welt des Mittelalters. Laaber: Laaber.

Heilmann, A. (2007). Boethius' Musiktheorie und das Quadrivium: eine Einführung in den neuplatonischen Hintergrund von "De institutione musica". Hypomnemata, 171. Göttingen: Vandenhoeck \& Ruprecht.

Heller, W. (1989). "Musik," Wörterbuch der Mystik, ed. P. Dinzelbacher. Stuttgart: Alfred Kröner Verlag, 366-67.

Hesse, H. (1990). The Glass Bead Game, trans. from the German by R. and C. Winston. New York: Henry Holt and Company.

Higgins, K. M. (2012). The Music Between Us: Is Music a Universal Language? Chicago and London: Chicago University Press.

Hijleh, M. (2019). Towards a Global Music History: Intercultural Convergence, Fusion, and Transformation in the Human Musical History. New York and London: Routledge.

Hildegard of Bingen (1988/1998). Saint Hildegard of Bingen, Symphonia. A Critical Edition of the Symphonia armonie celestium revelationum. With intro, trans., and commentary by B. Newman. Sec. ed. Ithaca, NY, and London: Cornell University Press.

Jaeger, C. S. (2012). Enchantment: On Charisma and the Sublime in the Arts of the West. Haney Foundation Series. Philadelphia, PA: University of Pennsylvania Press.

Kästner, H. (1978). Harfe und Schwert: der höfische Spielmann bei Gottfried von Straßburg. Untersuchungen zur deutschen Literaturgeschichte, 30. Tübingen: Max Niemeyer.

Kirmayer, L. J., C. M Worthman, S. Kitayama, and R. Lemelson (Ed.) (2020). Culture, Mind, and Brain: Emerging Concepts, Methods, and Applications, ed. L. J. Kirmayer, C. M. Worthman, Sh. 
Kitayama, and R. Lemelson. Current Perspectives in Social and Behavioral Sciences. Cambridge and New York: Cambridge University Press.

Kirsch, F. P. (Ed.) (2004). Möglichkeiten und Grenzen des Multikulturalismus: sprachlich-kultureller Vielfalt in Kanada und Europa, internationales Symposium Wien, 8. - 10. November 2001/The Protection of Cultural and Linguistic Diversity in Canada and in Europe/Comment et dans quelle mesure protéger la diversité linguistique et culturelle?, ed. F. P. Kirsch. Vienna: Zentrum für Kanada-Studien, Universität Wien.

Klein, T. R. (2015). "Grenzen der Menschheit: Marginalien zu Globalisierung und transkultureller Musikgeschichte," Musikhistoriographie(n): Bericht über die Jahrestagung der Österreichischen Gesellschaft für Musikwissenschaft, Wien, 21. bis 23. November 2013, ed. Michele Callela and Nikolaus Urbanek. Vienna: Hollitzer, 35-46.

Klein, T. R. (2020). "Lettern und Linien: Über Tonbuchstaben, fernöstliche Neumen und fernwestliche Dbyangs Yig," Von der Oralität zum SchriftBild: Visuelle Kultur und musikalische Notation (9.-13. Jahrhundert), ed. M. Nanni and K. Henkel. Theorie der musikalischen Schrift, 2. Leiden and Boston: Brill/Wilhelm Fink, 153-88.

Kleinschmidt, E. (1993). "Jörg Wickram," Deutsche Dichter der frühen Neuzeit (1450-1600): Ihr Leben und Werk, ed. S. Füssel. Berlin: Erich Schmidt Verlag, 494-511.

Klinksiek, A. (2016). Free Flow Energy: Die Heilkraft der Farben und Klänge. Hamburg: tredition.

Kobus, S. (2018). Musikalische Begleitung für Frühgeborene und ihre Familien. Wiesbaden: Ludwig Reichert Verlag.

Kruth, P. and H. Stobart (Ed.) (2000). Sound, ed. P. Kruth and H. Stobart. Cambridge: Cambridge University Press.

Kügle, K. (2015). "Conceptualizing and Experiencing Music in the Middle Ages (ca. 500-1500)," Handbook of Medieval Culture: Fundamental Aspects and Conditions of the European Middle Ages, ed. A. Classen. Vol. 2. Berlin and Boston: Walter de Gruyter, 1184-1204.

Lee, K.-H. (2002). Armut als neue Qualität der Helden im "Fortunatus" und im "Goldfaden". Würzburger Beiträge zur deutschen Philologie, 23. Würzburg: Königshausen \& Neumann.

Lee, M, L. Kianmei (Ed.) (2018). Gao Xingjian and Transmedia Aesthetics, ed. Mabel Lee and Liu Jianmei. Cambria Sinophone World Series. Amherst, NY: Cambria Press.

Levy, D. B. (1995/2003). Beethoven: The Ninth Symphony, rev. ed. Yale Music Masterworks. New Haven, CT: Yale University Press.

Lindahl Jacobsen, S., I. Nygaard Pedersen, and L. O. Bonde (Ed.) (2002/2019). A Comprehensive Guide to Music Therapy: Theory, Clinical Practice, Research, and Training, ed. Stine Lindahl Jacobsen. 2nd ed. London: Jessica Kingsley Publishers. 
Lindgren, U. (1992). Die Artes liberales in Antike und Mittelalter: bildungs- und wissenschaftsgeschichtliche Entwicklungslinien. Algorismus, 8. Munich: Institut für Geschichte der Naturwissenschaften.

Martianus Capella (1836). De nuptiis philologiae, et Mercurii, et de septem artibus liberalibus libri novem, ed. U. F. Kopp. Frankfurt a. M.: Varrentrapp, online now at: https://archive.org/details/denuptiisphilolo00martuoft (last accessed on June 13, 2021.

Martianus Capella (1977). Martianus Capella and the Seven Liberal Arts. Vol. 2: The Marriage of Philology and Mercury, trans. by W. H. Stahl. Records of Civilization, 84. New York: Columbia University Press.

McGlathery, J. (Ed.) (1992). Music and German Literature: Their Relationship since the Middle Ages. Studies in German Literature, Linguistics, and Culture. Columbia, SC: Camden House.

Mechthild of Magdeburg (1998). The Flowing Light of the Godhead, trans. and intro. by F. Tobin. The Classics of Western Spirituality. New York, and Mahwah, NJ: Paulist Press.

Mercer-Taylor, P. (2020). Gems of Exquisite Beauty: How Hymnody Carried Classical Music to America. New York: Oxford University Press.

Mishra, D. (2018). India Spirit: The Healing Power of Traditional India Music. Leipzig and Frankfurt a. M.: Deutsche Nationalbibliothek.

Möller, Ch. (2000). "Das 16. Jahrhundert," Kirchenlied und Gesangbuch: Quellen zu ihrer Geschichte. Ein hymnologisches Arbeitsbuch, ed. id. Mainzer Hymnologische Studien, 1. Tübingen and Basel: A. Francke Verlag, 69-127.

Mukherji, N. (2020). The Structure of the Human Mind: Explorations in Language, Music, Cartesian Sign. London: Bloomsbury Academic.

Müller, U. (2010). Gesammelte Schriften zur Literaturwissenschaft, ed. M. Springeth. 4 vols. Göppinger Arbeiten zur Germanistik, 750.1-4. Göppingen: Kümmerle.

Nielson, L. (2021). Music and Musicians in the Medieval Islamicate World: A Social History. Early and Medieval Islamic World. London: I.B. Tauris.

Norman, Ph (1996). Shout!: The Beatles in Their Generation. New York: Fireside; Encyclopedia of Popular Music, ed. Colin Larkin. New York: Oxford University Press.

Petersen, N. H. (2020). "The Beginning of Musical Notation and Carolingian Uses of the Term 'Sacrament': A Theological Perspective," Von der Oralität zum SchriftBild: Visuelle Kultur und musikalische Notation (9.-13. Jahrhundert), ed. M. Nanni and K. Henkel. Theorie der musikalischen Schrift, 2. Leiden and Boston: Brill/Wilhelm Fink, 1-16. 
Phipps, W. E. (2001). Amazing Grace in John Newton: Slave-Ship Captain, Hymnwriter, and Abolitionist. Macon, GA: Mercer University Press.

Richardson, J. (1996). "Niuwer David, Niuwer Orpheus: Transformation and Metamorphosis in Gottfried von Straßburg's Tristan," Tristania XVII: 85-109.

Roberts, P. (2012). From West to East and Back Again: An Educational Reading of Hermann Hesse's Later Work. Educational Futures, 51. Rotterdam and Boston: SensePublishers.

Roig-Francoli, M. A. (2007). Understanding Post-Tonal Music. Boston: McGraw-Hill Higher Education.

Savietto, V. (2019). Kunst und Künstler im Erzählwerk Klaus Manns: intermediale Forschungsperspektiven auf Musik, Tanz, Theater und bildende Kunst. Würzburg: Königshausen \& Neumann.

Schafer, R. M. (1994). The Soundscape: Our Sonic Environment and the Tuning of the World. Rochester, VT: Destiny Books.

Scherer, W. (1987). Hildegard von Bingen: Musik und Minnemystik. Freiburg i. Br.: Kore.

Schirrmacher, B. (2019). "Der wohltemperierte Erzähler: Die Gewalt ambivalenter Erzählung in Heinrich von Kleists 'Die heilige Cäcilie oder die Gewalt der Musik'," German Life and Letters 72.3: 279-96.

Seebass, T. (Ed.) (2012). Identities: The World of Music in Relation to Itself. Musicological Studies: Monographs, 17. Belgrade: Faculty of Music.

Sholl, R., S. van Maas (Ed.) (2017). Contemporary Music and Spirituality. London and New York: Routledge.

Steiner, R. (1983). The Inner Nature of Music and the Experience of Tone: Selected Lectures from the Work of Rudolf Steiner, trans. from the German by M. St. Goar and ed. by A. Wulsin. Spring Valley, NY: Anthroposophic.

Steinmetz, R.-H. (Ed.) (2001). Die Historia von den sieben weisen Meistern und dem Kaiser Diocletianus: Nach der Gießener Handschrift 104 mit einer Einleitung und Erläuterungen, ed. R.-H. Steinmetz. Altdeutsche Textbibliothek, 116. Tübingen: Max Niemeyer.

Strohm, R. (Ed.) (2021). Transcultural Music ed. Reinhard Strohm. Intercultural Music Studies, 24. Berlin: VWB -Verlag für Wissenschaft und Bildung.

Sulzer, D. (2019). Music, Math, and Mind: The Physics and Neuroscience of Music. New York: Columbia University Press. 
30| Rupkatha Journal, Vol. 13, No. 3, 2021

Taiwo, O. (2021). The Return Beat - Interfacing with Our Interface: A Spiritual Approach to the Golden Triangle. Oxford: Peter Lang.

Tendera, P. and W. Rubiś (2016). "World Music: A Transcultural Phenomenon," New Music Concepts: 2nd International Conference ICNMC 2016, ed. Della Ventura Michele. Vol. 2. Milan: Milano: ABEdiotre s.r.l, 61-82; online at: http://www.studiomusicatreviso.it/icnmc/library/Paper_20_2016.pdf (last accessed on June 15, 2021).

Thurman, K. (2021). Singing Like Germans: Black Musicians in the Land of Bach, Beethoven, and Brahms. Ithaca, NY, and London: Cornell University Press.

Tkotzyk, R. (2020). "Die musikalische Ambivalenz in Kleists Die heilige Cäcilie oder die Gewalt der Musik: Urteil über den Katholizismus oder Hilfsmittel zur Glaubensfindung?," Arcadia 55.1: 2543.

Tomasek, T. (1985). Die Utopie im "Tristan" Gotfrids von Strassburg. Hermaea, Neue Folge, 49. Tübingen: Max Niemeyer.

Tomasek, T. (2007). Gottfried von Straßburg. Hermaea / Neue Folge, 49. Stuttgart: Philipp Reclam jun.

Vaget, H. R. (2006). Seelenzauber: Thomas Mann und die Musik. Frankfurt a. M.: Fischer.

Wagner, D. L. (1983). The Seven Liberal Arts in the Middle Ages. Bloomington, IN: Indiana University Press.

Weiß, T. (2007). Minnesang und Rock - die Kunstgattung Aufgeführtes Lied in ihrer Ästhetik und Poetik: moderne Zugänge zu einer alten Liedgattung, Aufführung und ihre Bedingungen für die Liedtextinterpretation. Neustadt am Rübenberge: Rübenberger Verl. Weiß.

Westermann, E. B. (2021). Drunk on Genocide: Alcohol and Mass Murder in Nazi Germany. Battlegrounds: Cornell Studies in Military History. Ithaca, NY: Cornell University Press.

Wickram, J. (1991). Der Goldfaden (1557): The Golden Thread, trans. P. Kaufke. Pensacola, FL: University of West Florida Press.

Womack, K. (Ed.) (2009). The Cambridge Companion to the Beatles. Cambridge Companions to Music. Cambridge: Cambridge University Press. 